\title{
First-Year Students' Participation And Performance In A Financial Accounting Support Group
}

Eloise de Jager, University of Stellenbosch, South Africa Eli Bitzer, University of Stellenbosch, South Africa

\begin{abstract}
The academic performance and retention of first-year students are under scrutiny worldwide. In view of the emphasis on first-year success, a support group was established in a first-year module - Financial Accounting 178 - at Stellenbosch University in South Africa. The article reports on students' perceptions of their participation and their pass rates within the support group. Both qualitative and quantitative data were obtained from interviews, questionnaires, and an analysis of support group pass rates. The overall conclusion from this study is that students in financial accounting perceived their participation as positive and an increase in pass rates, compared to previous results, was observed. Small-group participation, tutorial classes, and peer student assistance all appear to contribute positively to improved performance of support groups. A number of areas for possible future research were identified from the results.
\end{abstract}

Keywords: Perceptions of First-Year Students; Financial Accounting; Support Group; Small Group; Tutorial Classes; Pass Rates

\section{INTRODUCTION}

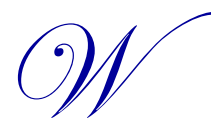

orldwide, there is particular interest in the pass rates of first-year university students as student performance and success in a first year of study provides the basis for further success in degree programmes (Crabtree, Roberts \& Tyler, 2007). In South Africa, myths, rumours, perceptions and opinions abound about low pass rates among first-year students (Du Plessis, Prinsloo \& Muller, 2005; Scott, Yeld \& Hendry, 2007). It appears as if factors, such as language proficiency, educational background, race, and personal characteristics, play a role in students' lack of achievement. In accounting, in particular, there seems to be a need for specific strategies to improve the quality of student learning which, in turn, may raise pass rates (Accountancy SA, 2008). Several researchers (Watson, 2000; Muller, Prinsloo \& Du Plessis, 2007; Prinsloo \& Van Rooyen, 2007; Scott, 2009) regard support measures to improve the pass rate of accounting students as being important. As the quest to change effectiveness in accounting education is prominent, accounting educators are urged to place less emphasis on lecturing and to introduce strategies to emphasise active learning activities (Albrecht \& Sack, 2000).

Various academic support programmes have been introduced at higher education institutions that are being challenged to provide effective and sufficient academic support (Jones \& Watson, 1990; Crosling \& Webb, 2002; Joubert, 2010). Also, there seems to be evidence that collaborative learning is a learning approach that is helpful to students (Hughes, 2007). Such an approach, where two or more students learn or attempt to learn together, has been shown to be associated with improved pass rates (Dillenbourg, 1999; McDowell, Werner, Bullock \& Fernald, 2006; Biggers, Yilmaz \& Sweat, 2009). However, it is necessary to ask what students' perceptions are regarding the academic assistance and support provided through support programmes of this nature and whether they perceive it to be effective. Limited work has been published in accounting literature on how students experience academic support and assistance (Williams, Tiller, Herring \& Schiener, 1988). 
The study on which this article is based focused on the perceptions and pass rates of students participating in a support group in a first-year financial accounting module at Stellenbosch University. The students in question received additional academic support during either their first or second semester of their first-year studies. The support programme was first introduced in 2005 and the study focused on the 2008 year group. Due to the scant literature on the way in which students' attitudes and perceptions play an important role in their learning success (Bennett, Green, Rollnick \& White, 2001), the aim of this study was to determine the possible link between student perceptions of academic support and their pass rates.

The findings of this study add to the body of knowledge related to teaching of the first-year students in financial accounting. In particular, in previous research the use of academic support was investigated, also taking into account the South African context where factors, such as race and language, play an important role in student success (Mabokela \& Mawila, 2004; Muller et al., 2007; Prinsloo \& Van Rooyen, 2007). For instance, independent studies have indicated that students' language proficiency is a determinant of success in introductory financial accounting (Steenkamp, Baard \& Frick, 2009) and that race, as a variable, has a substantial influence on pass rates (Horn, Jansen \& Yu, 2008).

\section{BACKGROUND}

Financial Accounting 178 is a core module in the Bachelor of Accounting curriculum at Stellenbosch University. While Financial Accounting 178 is a compulsory module in the first year of study, a pass mark in this module is also required for admission to several second-year modules in this programme. Therefore, if students fail the financial accounting module in the first year, the pass rate in the programme is directly affected (Muller, Prinsloo \& Du Plessis, 2007).

A large number of students regard financial accounting as the most difficult of all their modules (author's own experience). Based on this perception and a number of supporting factors, such as maintaining high first-year pass rates and supporting formerly disadvantaged students, an additional support group for Financial Accounting 178 was introduced in 2005. The support programme entailed receiving lecturers in small groups, tutorial classes and help from student assistants. The aim of introducing this group was to help students, especially those who were formerly disadvantaged by inequalities in the schooling system in South Africa (Lomofsky \& Lazarus, 2001), to pass financial accounting. While Stellenbosch University has created various opportunities for support at an institutional level, this support group model is one of the mechanisms that have been implemented at the departmental level.

Tait (2000) and Scott (2009) view support as serving three primary functions; namely, cognitive (academic) support, affective (emotional or pastoral and social) support, and systematic (administrative) support. However, in the case of Financial Accounting 178, a support group was mainly introduced to provide cognitive support. As Tinto (1975) pointed out, both academic and social support to promote student retention are important for student success. In this particular support programme, this was accomplished by enhancing academic, as well as social, interaction among support group students.

In accordance with Fourie's (2006) suggestion that support should be made available to students who fail their first semester test, the support group programme reported on in this study (implemented in 2005) entailed allocating students and one lecturer to a support group. The marks obtained in Grade 12 for mathematics and accounting, as well as the results of the students' access tests at Stellenbosch University, were taken into consideration to allocate students to one support group at the beginning of the first semester. The progress marks after the first semester were taken into consideration to allocate the students at the beginning of the second semester. All Thuthuka students (formerly disadvantaged students funded by the South African Institute for Chartered Accountants) were also required to attend the support group in both semesters. This ensured that poorly performing and previously disadvantaged students were included in the support group. The support group was limited to a maximum of 70 students, whereas the mainstream (non-supported) groups consisted of approximately 180 students. One lecture hall was allocated for the support group (to keep the lecture environment consistent), but the content of the material remained exactly the same as that of the mainstream students. The students of the support group had six scheduled class periods per week, as opposed to four for the mainstream students. This provided more time for 
practical tutorial classes. Tutorial classes, where students could work on particular questions or problems in smaller groups, constituted two class periods (i.e., 100 minutes) scheduled every Friday. The students worked on the questions and problems with their peers and with the assistance of student assistants/tutors and the lecturer. After each tutorial session, the solution to the posed problem or question was distributed to students. Students allocated to the support group were encouraged to attend at least $80 \%$ of the classes and, by the end of the first semester, the group was reconstituted based on the students' progress during the first semester. However, many other students also joined the support group voluntarily, especially in the second semester when underachievers realised that they were in need of additional assistance.

It is important to note that the support group activities were aligned to those of the mainstream students and the lecturers did not regard the support as a remedial measure. Research has shown that the efficiency of an academic support programme is impaired if it is not well integrated with mainstream teaching and learning activities (Richardson \& Bender, 1987), hence the measure to align academic support with the mainstream programme and its day-to-day learning activities. The programme was aimed at integrating the support group with the mainstream students so that the students did not regard the support group as being separate from the mainstream financial accounting module. The aim was rather to support those students who may have lacked particular academic skills and knowledge at particular stages in the module. The lectures attended by support group students, therefore, ran parallel with and were synchronised to the lectures attended by the mainstream groups. However, two additional tutorial classes were offered to support group students.

\section{LITERATURE STUDY}

From a theoretical perspective related to small-group support actions, the following four issues emerged: positive student perceptions, the effectiveness of learning, the value of student assistance and tutorials, and the improvement in student performance:

\section{Positive Student Perceptions}

The first-year experience of students is critical to their overall success at university (Siegel, 2007). Part of enhancing first-year success is the availability of alternatives to traditional lectures and support measures. More important, however, is how students perceive and participate in alternative and support measures as it has been well established that students' perceptions of their learning environments and opportunities have an impact on their learning outcomes (Entwistle, 1998; Lord \& Robertson, 2006). Moreover, students' perceptions of their learning environments have been shown to be a good predictor of learning success (Ballantine \& McCourt Larres, 2009; Lizzio, Wilson \& Simons, 2002) and are positively correlated to successful learning in smaller and collaborative groups (Caldwell, Weishar \& Glezen, 1996; Evenson, 2004).

According to Byrne and Flood (2005), lecturers in accounting sometimes seem unaware of the important role of student perceptions. In the South African context, in particular, it can be expected that students of different backgrounds and academic histories may have different views and perceptions of their academic environments - in particular when there may be some risk that non-mainstream students are 'labelled' as being incapable of coping with mainstream activities (Carpenter, Friar \& Lipe, 1993; Caldwell et al., 1996; Evenson, 2004).

\section{Effectiveness Of Learning In Small Groups}

An important aspect of academic support is that it includes the use of smaller student groups (Cottell \& Millis, 1992). Research into small-group learning (Greenwood, Delquadri \& Hall, 1989; Sideridis, Itley, Greenwood, Dawson \& Delquadri, 1998, cited in Sideridis \& Kaissidis-Rodafinos, 2001) has established positive correlations between active student involvement in small groups and academic success. Although small groups may vary in contexts, where class groups are smaller than 80 and tutorial groups smaller than 10 students, learning success has been ascribed to students' constructive participation in group activities (Biggs, 1999).

Some of the advantages of being part of a smaller group are that students feel free to ask questions (Steinert, 2004), are more comfortable in class (Murray-Harvey and Slee, 2000; Lord \& Robertson, 2006; Steinert, 
2004) and feel less intimidated than they would in a large group (Murray-Harvey \& Slee, 2000). Students also appear to be more self-confident in small groups (Adonis, 2001).

Research into the use of smaller learning groups in higher education institutions in the United Kingdom has indicated that while students are traditionally passive absorbers of course material in classes, small-group learning promotes the understanding of topics and assists students in acquiring a deeper knowledge of learning material (Martins \& Walker, 2005). In general, more effective learning is therefore associated with small-group learning activities.

\section{The Value Of Student Assistants And Tutorials}

Tutorial classes offer first-year students the opportunity to benefit not only from other students in their own year group, but also from second-year students (student assistants) following the same degree programmes (Gross \& McMullen, 1983; Lord \& Robertson, 2006). Leveson (1999) showed, by comparing students' learning success in accounting and their other subjects, that they could handle tutorial assignments more effectively as a result of volunteer tutorial groups in an accounting module. Moreover, they managed their time more effectively and were more successful in their interpersonal relationships.

Isaacs (2007) also regards tutorial classes as being more dynamic in creating smaller group contexts for more meaningful discussion, supporting learning by means of more personal and individual attention, and providing a platform for free and open discussions. Lord and Roberson (2006) found that students perceive tutorials as providing opportunities for deep inquiry, while at the University of Alabama it was found that students had favourable responses to peer tutoring programmes which involved student assistants (Bush, 1985).

\section{Student Academic Performance}

The pass rate of first-year students has been a cause for concern for many years, both nationally and internationally (McInnis \& James, 1995). In the South African context, De Klerk, Schoeman, Van Deventer and Van Schalkwyk (2006) have pointed out that it seems crucial to urgently address high failure rates among first-year students as the success in the first year of study is of extreme importance for continued success.

Evidently, student academic success depends on an array of interdependent variables (Prinsloo \& Van Rooyen, 2007). Factors that may influence students' success and pass rates include race, gender, home language, previous subject knowledge and success, time management skills, as well as the student's motivation to succeed (Muller, Prinsloo \& Du Plessis, 2007; Steenkamp, Baard \& Frick, 2009). Tinto's model of academic and social integration also provides a foundation to analyse factors that play a role in students' pass and retention rates (Braxton, 2000).

Establishing student support groups has been indicated as one factor - but an important one - that increases the pass rates of students (Sadler \& Erasmus, 2005). Johnston (1997) suggests academic support groups as a possible strategy to improve pass rates, while Tinto (2002: 3) states emphatically that "support is a condition that promotes student retention". There is an improvement in performance of students who participate in support programmes (Fox \& Stevenson, 2006; Hall, Hendriksen, Love \& Yang, 2005).

Academic performance is also related to an increase in student diversity in higher education (Cross, 2004). Such an increase in diversity has resulted in different pass rates for different student profiles in support groups and seems relevant to variables such as race (Sadler \& Erasmus, 2005; Horn, Jansen \& Yu, 2008) and language (Steenkamp, Baard \& Frick, 2009) - particularly in the South African context. These are important findings which may alert universities and lecturers to creating support groups as well as to possible support strategies.

At Stellenbosch University, Fourie (2006) has pointed out that many first-year students fail financial accounting, even if they had accounting as a school subject in Grade 12. Furthermore, figures reported by Higher Education South Africa (HESA) (Neves, 2008) drew attention to the fact that $35 \%$ of the students at some universities do not successfully complete their studies; the bulk of these being first-year students. Moreover, the 
literature makes a good case for research into the use of support groups in a module, such as Financial Accounting 178 , in order to consider the improvement of first-year pass rates.

\section{AIM OF THE STUDY}

The aim of the study was to 1) determine students' perceived experiences of their involvement in a support group in a financial accounting module at Stellenbosch University and 2) determine whether their participation promoted actual academic performance. The differences between race and language were also identified, due to the importance thereof in the South African context.

One of the aims of the study was to inform the Department of Accounting at Stellenbosch University, as well as the South African Institute for Chartered Accountants (SAICA), of the possible benefit of small-group learning in promoting student success. A further aim was to add to the body of knowledge on support measures and structures for first-year students and to provide guidance to other institutions that may wish to implement similar interventions.

\section{METHODOLOGY}

A mixed method approach (Creswell, 1994) was used to generate both qualitative and quantitative data. In this study, the "sequential mixed method design" (Creswell, 1994) was applied, incorporating both quantitative and qualitative research procedures. Most of the quantitative research was done after the qualitative interviews had been analysed.

The qualitative part of the study entailed conducting interviews with a sample of the students and the two student assistants who were allocated to the support group. The quantitative part of the study entailed a crosssectional survey among students participating in the support group and analysing their performance marks.

Questions used in the interviews and questionnaires were based on the issues highlighted and related to support groups by literature. Possible dimensions of the perceptions of support groups guided the formulation of interview questions and survey items, the latter which appear in Tables 1 to 4 . The study focused on first-year students who participated in a support group for Financial Accounting 178 in 2008.

Data were generated through interviews with a purposive sample of students in the support group (six at the beginning of the year and nine at the beginning of the second semester) and a questionnaire survey among all support group members in the two weeks after the beginning of the 2008 academic year. The survey was repeated within two weeks after the beginning of the second semester. At the end of the 2008 year, unstructured interviews were conducted with the two student assistants by asking them about their experiences in providing assistance. Finally, after the examinations, student performance marks were captured.

The students were not in the least pressurised to complete the questionnaire and were clearly informed verbally and in writing that participation was voluntary. Students were also assured of the anonymity and confidentiality of responses and no student could be identified in the survey results. Also, the researchers ensured that student performance marks could in no way be influenced by the research process.

\section{DATA ANALYSIS}

Interview data were transcribed, coded, and categorised according to themes. Quotes in the results section of this article represent typical responses received and were selected to support the results and the points raised. Frequency analyses were performed on 86 responses from the students who were required to attend the support group; the responses of the voluntary students were removed for purposes of the study. Responses to open-ended questions are reported verbatim in this article. The academic performance of support group students was also compared to similar students' performance prior to support group participation. Descriptive statistics were used to present student performance results. 


\section{RESULTS}

\section{Survey Response Rates And Participant Profiles}

Out of a total of 48 semester 1 support group students, 47 rendered feedback - a response rate of $97 \%$. In semester 2, feedback was received from 39 out of 67 support group students - a response rate of $58 \%$. The low response rate from the second semester group can be ascribed to the low class attendance, presumably due to midsemester tests. The low class attendance was in contrast with that of the rest of the semester.

The profile of participating support group students in the first and second semesters is indicated in Figures 1 and 2 , respectively.

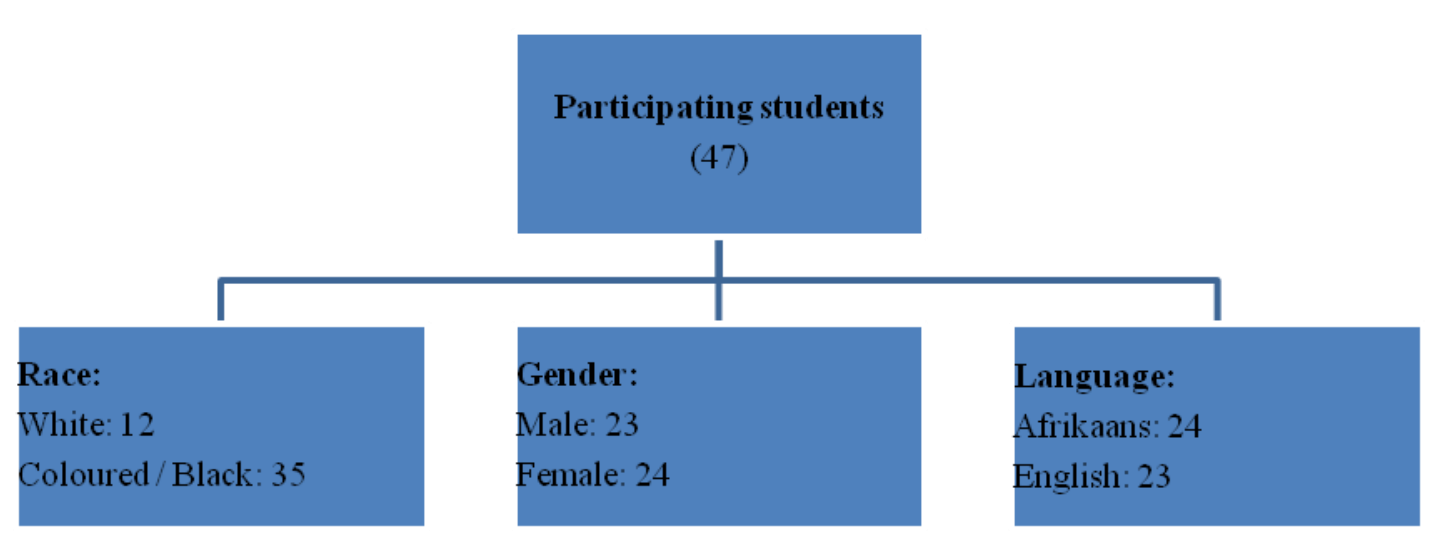

Figure 1: Student Profile Of Survey Completers In Semester 1

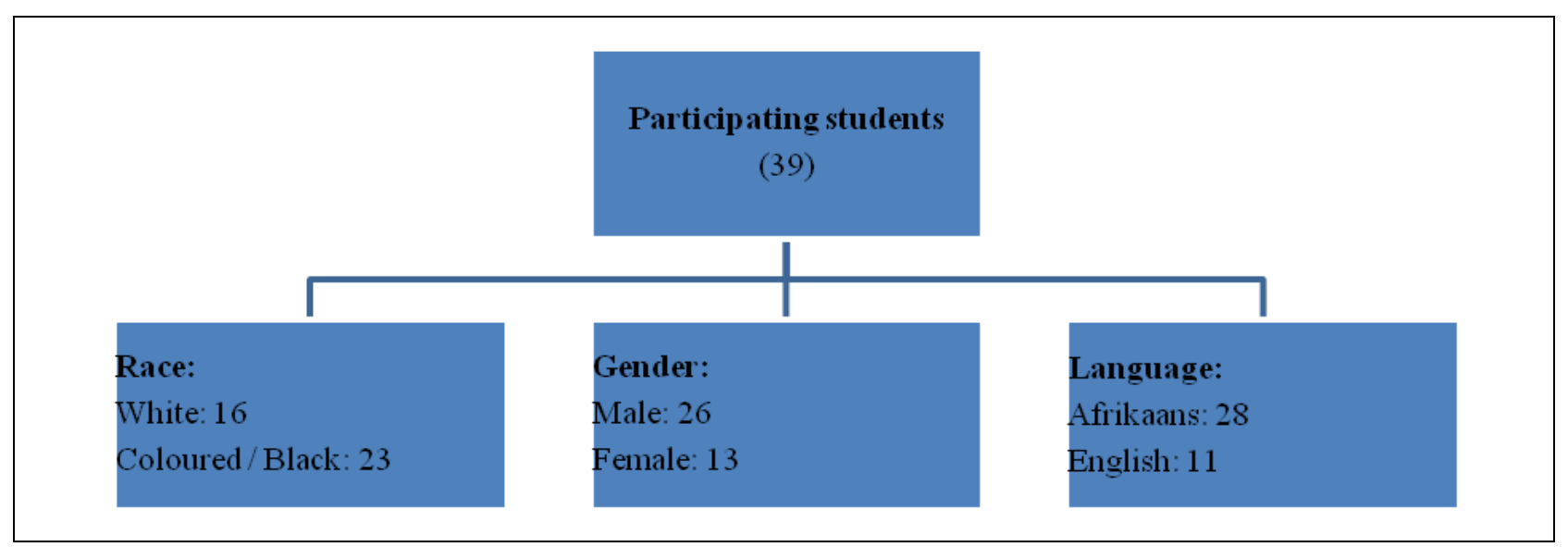

Figure 2: Student Profile Of Survey Completers In Semester 2

\section{Student Perceptions On Being Part Of The Support Group}

Survey results reflected that students initially experienced mixed feelings (36 students agreed and 43 students disagreed) about being placed in a support group (see Table 1). The results, however, proved that since the beginning of the semester until the questionnaires were handed out two weeks later in the relevant semesters, the support group participants experienced more positive feelings in this regard (see Table 2). 
Table 1: Support Students' Response To The Statement, 'I Was Unhappy When I Was Allocated To The Support Group At The Beginning Of The Year/Second Semester'

\begin{tabular}{|c|c|c|c|c|}
\hline & Aoree & Disagree & & Total \\
\hline Semester 1 & $19(40 \%)$ & $23(49 \%)$ & $5(11 \%)$ & 47 \\
\hline White & $3(25 \%)$ & $9(75 \%)$ & 0 & 12 \\
\hline Coloured / Black & $16(46 \%)$ & $14(40 \%)$ & $5(14 \%)$ & 35 \\
\hline Afrikaans & $10(42 \%)$ & $10(42 \%)$ & $4(16 \%)$ & 24 \\
\hline English & $9(39 \%)$ & $13(57 \%)$ & $1(4 \%)$ & 23 \\
\hline Semester 2 & $17(43 \%)$ & $20(51 \%)$ & $2(5 \%)$ & 39 \\
\hline White & $11(69 \%)$ & $4(25 \%)$ & $1(6 \%)$ & 16 \\
\hline Coloured / Black & $6(26 \%)$ & $16(70 \%)$ & $1(4 \%)$ & 23 \\
\hline Afrikaans & $14(52 \%)$ & $12(44 \%)$ & $1(4 \%)$ & 27 \\
\hline \multirow[t]{2}{*}{ English } & $3(25 \%)$ & $8(67 \%)$ & $1(8 \%)$ & 12 \\
\hline & 36 & 43 & 7 & 86 \\
\hline
\end{tabular}

Table 2: Support Students' Response To The Statement, 'Currently I Don't Mind Being Part Of The Support Group'

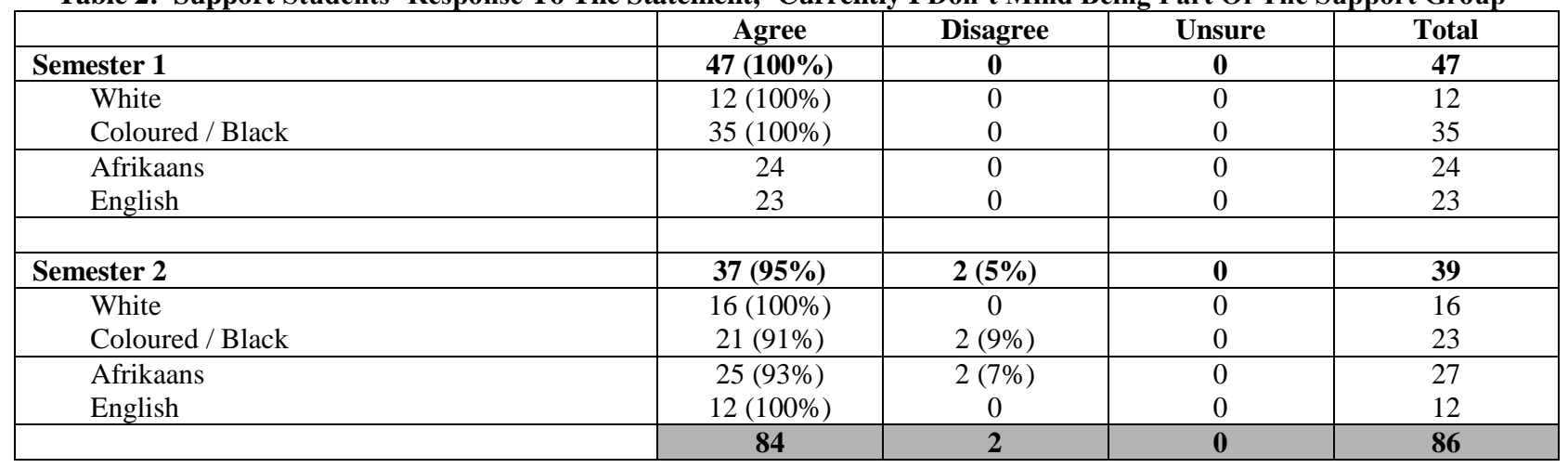

In the first semester, fewer white students (25\%) were uncomfortable (unhappy) at being allocated to the support group compared to the second semester (69\%), whereas more coloured/black students (44\%) were unhappy at being allocated to the support group in the first semester than in the second semester (26\%). Overall, fewer white students $(39 \%)$ were unhappy at being allocated to the support group than coloured/black students $(61 \%)$.

In the first and the second semester, about half of the Afrikaans students were unhappy at being divided into the support group while the majority of the English students did not mind being allocated to the support group in the first $(57 \%)$ or the second semester (67\%). Overall, however, (first and second semester) more Afrikaans (67\%) students were unhappy about support group membership than English students (33\%).

\section{Student Perceptions On Participation In Small Groups}

The perceptions of all participating students about lectures in a smaller class group were positive, except in two cases (see Table 3). Consequently, there were no differences by race or language.

The majority of students commented that they were more at ease to ask questions and more involved in smaller group situations. Typical comments rendered by support group students were:

We are able to ask questions; and I think we can interact with our lecturers, like on a more personal level. And we are getting familiar with our classmates, so in that way can also ask one another.

It's not that pressurising as the other class; the support group is much more comfortable to work in.

You feel more like it's a personal thing with the class and the lecturer.

2013 The Clute Institute http://www.cluteinstitute.com/ 
Table 3: Support Students' Response To The Statement, 'I Think It Is Advantageous To Learn In A Smaller Group'

\begin{tabular}{|l|c|c|c|c|}
\hline & Agree & Disagree & Unsure & Total \\
\hline Semester 1 & $\mathbf{4 6}(\mathbf{9 8 \%})$ & $\mathbf{0}$ & $\mathbf{1}(\mathbf{2 \%})$ & $\mathbf{4 7}$ \\
\hline White & $11(92 \%)$ & 0 & $1(8 \%)$ & 12 \\
Coloured / Black & $35(100 \%)$ & 0 & 0 & 35 \\
\hline Afrikaans & $23(96 \%)$ & 0 & $1(4 \%)$ & 24 \\
English & $23(100 \%)$ & 0 & & \\
\hline & & & & \\
\hline Semester 2 & $\mathbf{3 7}(\mathbf{9 6 \%})$ & $\mathbf{2 ( 4 \% )}$ & $\mathbf{0}$ & $\mathbf{3 9}$ \\
\hline White & $14(88 \%)$ & $2(12 \%)$ & 0 & 16 \\
Coloured / Black & $23(100 \%)$ & 0 & 0 & 23 \\
\hline Afrikaans & $27(96 \%)$ & $1(4 \%)$ & 0 & 28 \\
English & $10(91 \%)$ & $1(9 \%)$ & 0 & 11 \\
\hline
\end{tabular}

Another matter that emerged from students' responses concerning the advantages of a smaller group setting is that the support group probably grew too large in the second semester. Although only 67 students were allocated to the support group in the second semester, more students voluntarily joined this group. In the first semester, 48 students were allocated to the support group, while only eight students joined the group voluntarily. Comments regarding the support group class size in the second semester included:

Subdividing the support group into two or more smaller groups

Class is still big to a degree.

It is really distracting having the bigger class and defeats the purpose of the support group.

Limit the number of students that attend the support group because the class gets overcrowded.

\section{Student Perceptions On Student Assistants And Small-Group Tutorials}

The results (see Table 4) indicated that there were mixed feelings about student assistants attending to tutorial classes. Most students (74 out of 86 responses) reported that student assistants were helpful, but some (6 out of 86 responses) found them of no help at all. There were no differences in perceptions concerning factors such as race or language.

Table 4: Support Students' Responses To The Statement,

'I Feel The Student Assistants Helped Me During The Tutorial Classes'

\begin{tabular}{|l|c|c|c|c|}
\hline & Agree & Disagree & Unsure & Total \\
\hline Semester 1 & $\mathbf{4 0}(\mathbf{8 5 \%})$ & $\mathbf{4}(\mathbf{9 \%})$ & $\mathbf{3}(\mathbf{6 \%})$ & $\mathbf{4 7}$ \\
\hline White & $11(92 \%)$ & 0 & $1(8 \%)$ & 12 \\
Coloured / Black & $29(83 \%)$ & $4(11 \%)$ & $2(6 \%)$ & 35 \\
\hline Afrikaans & $19(79 \%)$ & $3(13 \%)$ & $2(8 \%)$ & 24 \\
English & $21(91 \%)$ & $1(4 \%)$ & $1(4 \%)$ & 23 \\
\hline & & & & \\
\hline Semester 2 & $\mathbf{3 4 ( 8 7 \% )}$ & $\mathbf{2 ( 5 \% )}$ & $\mathbf{3 ( 8 \% )}$ & $\mathbf{3 9}$ \\
\hline White & $14(88 \%)$ & $1(6 \%)$ & $1(6 \%)$ & 16 \\
Coloured / Black & $20(87 \%)$ & $1(4 \%)$ & $2(9 \%)$ & 23 \\
\hline Afrikaans & $25(89 \%)$ & $1(4 \%)$ & $2(7 \%)$ & 28 \\
English & $9(82 \%)$ & $1(9 \%)$ & $1(9 \%)$ & 11 \\
\hline
\end{tabular}


Positive observations related to support by assistants from both the interviews and questionnaires included the following:

- $\quad$ Student assistants and support students were perceived to be 'more on the same level'; it made it easier for students to ask questions and was perceived as less threatening (also see Gross \& McMullen, 1983).

- The student assistants explained the work in a different way, and sometimes even more clearly than the lecturer, resulting in students finding the work easier to follow.

\section{Perceptions Of Student Assistants}

Student assistants were also positive about tutorials. They remarked that students were comfortable about approaching them for advice and saw it as beneficial for support students to learn from one another. Their comments included:

In Financial Accounting, practice is essential to master the work. These tutorial classes forced them to do so without putting any pressure on them to get it right the first time round.

Some of them also mentioned to me that the extra classes help a lot since it forces them to work out an additional question.

\section{Analysis Of Student Academic Performance}

The pass rates of all support group students in 2008 were captured and compared to those of students in the mainstream group, as well as to those of the non-support group of 2004. The non-support group, in this case, constituted those students who were eligible for support in 2004 but when there was no such programme in place (as the support group programme only started in 2005).

Table 5: Pass Rates Of The Support And Mainstream Group

\begin{tabular}{|l|c|c|}
\hline & Support Group & Mainstream Group \\
\hline Total number of students in the support/mainstream group during the year & 87 & 270 \\
\hline Number of students passed & $48(55 \%)$ & $247(91 \%)$ \\
\hline $\begin{array}{l}\text { Total number of students in the support/mainstream group admitted to } \\
\text { examination }\end{array}$ & 71 & 262 \\
\hline Number of students that passed & $48(77 \%)$ & $247(94 \%)$ \\
\hline
\end{tabular}

Table 5 indicates that the aggregated pass rate of the support group during 2008 was $55 \%$ and $91 \%$ for the mainstream group. Included in these figures are the marks of students who did not receive a class mark - students who were not allowed into the final examination. If the latter group of students are left out of the equation, then the pass rate of the support group was $77 \%$ and $94 \%$ for the mainstream group. These figures represent students that passed either in the first examination or the supplementary examination. From the statistics, it is clear that the support group did not match the academic achievements of the mainstream group but that the influence on the overall mark without support would have been worse in the case of no support offered.

Table 6: Pass Rates Of The Support Group Per Race And Language

\begin{tabular}{|l|c|c|c|c|}
\hline & Passed & Failed & Not Admitted To The Examination & Total \\
\hline $\begin{array}{l}\text { Total In The Support Group } \\
\text { During The Year }\end{array}$ & $\mathbf{4 8 ( 5 5 \% )}$ & $\mathbf{2 3 ( 2 6 \% )}$ & $\mathbf{1 6}(\mathbf{1 8 \% )}$ & $\mathbf{8 7}$ \\
\hline White & $20(48 \%)$ & $13(31 \%)$ & $9(21 \%)$ & 42 \\
Coloured / Black & $28(62 \%)$ & $10(22 \%)$ & $7(16 \%)$ & 45 \\
\hline Afrikaans & $33(63 \%)$ & $11(21 \%)$ & $8(15 \%)$ & 52 \\
English & $15(43 \%)$ & $12(34 \%)$ & $8(23 \%)$ & 35 \\
\hline
\end{tabular}


From Table 6, it can be seen that the pass rate of the white students (48\%) was well below the pass rate of the coloured/black students (62\%). Similarly, the pass rate for Afrikaans students (63\%) was considerably higher than for English students (43\%).

If the pass rate of support students (55\%) in 2008 is compared to the pass rate of students who would have been included in the support group (37\%) in 2004 - the year before the support group programme was introduced (see Table 7), it appears that the introduction of the support group programme played a positive role in increasing pass rates. There was, however, an insignificant difference in the percentage of students who were allowed to write the examination in the two comparing years (pass rates of $71 \%$ and $73 \%$, respectively). These figures indicate that most students who were admitted to the examination were successful.

Table 7: Pass Rates Of Students Who Would Have Been Allocated To The Support Group In The Year Before The Support Group Was Established

\begin{tabular}{|l|c|}
\hline Total number of students who would have been in the support group during the year & 105 \\
\hline Number of students passed & $39(37 \%)$ \\
\hline $\begin{array}{l}\text { Total number of students who would have been in the support group admitted to write the } \\
\text { examination }\end{array}$ & 53 \\
\hline Number of students passed that was admitted to write the examination & $39(73 \%)$ \\
\hline
\end{tabular}

\section{DISCUSSION}

The main findings of this study indicated that, initially, support students had mixed feelings about being allocated to a support group. After some time in the particular two semesters, however, the majority of these students appreciated being part of the group. The lecturers expected that students might possibly feel uneasy about being allocated to the support group because they were singled out from the rest of the students. However, they also expected that the students would settle down once they were used to being part of a support group and saw its advantages. Even though it may be argued that students felt singled out, their change in attitude proved to be positive and in accordance with earlier research on support group participation (Caldwell et al., 1996; Evenson, 2004). The reasons for the scattered differences in experience, according to race, could not be determined from the questionnaire and may be a topic for future study. English-speaking students were more positive about being allocated to the support group, even though lectures in the support group were only presented in Afrikaans. It is possible that English-speaking students might have expected more personal attention and work to be repeated in English during small group tutorials.

Lecturers in financial accounting at Stellenbosch University agree that tuition offered in small groups holds many advantages over lecturing to larger groups because in the former instance, students are less intimidated and feel free to ask questions. These views are supported by earlier research on lecturer expectations of support groups (Murray-Harvey \& Slee, 2000; Steinert, 2004). The students had a positive perception of small-group formation since it offered them the opportunity to ask questions freely and to be actively involved in their learning. These findings concur with other research on student support (Steinert, 2004; Martins \& Walker, 2005). One concern that emerged was that, in the second semester of implementation, the support group became too large due to students who voluntarily attended the group. The positive effects of a smaller class group setting is jeopardised when the class exceeds a certain size; in this case, it was experienced to be around 60 students. These findings may point to the fact that student support class groups in financial accounting should be kept below 60 participants per group for lecture-type activities. This also concurs with similar findings which support that student success is associated with groups of fewer than 80 students per class group (Biggs, 1999).

The introduction of small-group tutorials for the financial accounting support group was a further step toward assisting students who seemed to struggle academically. Wood and Olivier (2004) describe student assistants as more senior students with a slightly higher ability than first-year students and who have already achieved firstyear learning goals. In support of group tutorials, first-year students were offered opportunities to learn from secondyear students and from one another (peers). Having already passed this module, the second-year students were aware of aspects that first-year students found problematic and could assist them where necessary. It was evident that support students enjoyed learning from second-year students - often because they found them to be more 
understanding. They appeared to feel less intimidated than when they were being supported by the lecturer. These observations largely confirm findings from earlier research in learning support contexts (Gross \& McMullen, 1983). The majority of support students perceived small group tutorials and student assistants as being positive supportive measures. This finding corresponds with research by Gross and McMullen (1983), as well as Lord and Robertson (2006), who found that first-year students, in general, benefit from assistance of their peers as well as from that of second-year students. Student assistants and support students were perceived to be 'more on the same level'; which made it easier for students to ask questions and was perceived as less threatening (also see Gross \& McMullen, 1983).

However, negative feedback from a minority of support students indicated that they prefer to do tutorials on their own or, rather, to consult the lecturer as they did not understand the way the work was explained to them by the assistants. One of the disadvantages of peer support seems to be that support students sometimes copy answers from others (Leveson, 1999). This view corresponds with the feedback of one of the student assistants:

\section{They don't try to attempt the questions on their own and just copy it.}

Student assistants also perceived small group tutorials as being positive in that support students were comfortable in approaching them. They also observed that it may be beneficial for support students to learn from one another as well. The overall observation was that small-group tutoring promoted active participation and learning (also see Lee, 2005; Lord \& Robertson, 2006). The difference in the way the students in the support group learned was that they were able to participate more, they could interact with each other, they could interact with the lecturer, they were guided through examples and questions, lecturers could ask questions, and support students were more comfortable answering questions than in a larger class.

An analysis of pass rates indicated that 55\% of the support students did indeed pass the module. If this figure is compared to the pass rate of students in the year just before the support group was established - when no support existed (37\%) - the difference is obvious and could possibly be ascribed to the positive influence of support group participation. Although the pass rate of support students was much lower than that of the mainstream students (91\%), it is important to note that no - or less - support could have been even less favourably comparable to the pass rates of mainstream students. It should also be noted that student success depends on multiple and interrelated sets of variables and it may be inaccurate to ascribe increased student success solely to the influence of support group participation. The reason for the differences in pass rates according to race could not be determined, but the white students who joined the support group might have been exceptionally weak or relied too much on support activities rather than on own effort. The reason for the differences in pass rates according to language could also not be determined but could probably be ascribed to the fact that the support group received lectures in Afrikaans. However, this could not be verified as many factors may influence pass rates. It appears that the introduction of the support group programme played a positive role in increasing pass rates. The success of the intervention depends on the increase in pass rates, which indeed seemed to be the case.

\section{CONCLUSION}

The aim of the reported study was to determine the perceived experiences and pass rates of first-year students involved in a financial accounting support group at Stellenbosch University. Within the context of the high failure rates among first-year students (Du Plessis, Prinsloo \& Muller, 2005) and their possible exposure to support programmes at higher education institutions, the study aimed to establish how students experience the various elements of the support programme. The study focused mainly on the perceptions of support students, but it also included the perspectives of the student assistants, as well as an analysis of support students' pass rates.

The overall conclusion from this study is that students in financial accounting perceived their participation as being positive. Furthermore, an increase in pass rates, compared to previous results, was observed. Small-group participation, tutorial classes, and peer student assistance all appear to contribute positively to improved performance of support groups in financial accounting. 
As is the situation in most single cross-sectional case studies, there were a number of limitations to the study and the initial implementation of support group programmes. The following limitations may be relevant:

- The study comprised a single case, in a single year at a single university, not representative of the population of first-year students in accounting in higher education. However, the aim of the study was not to generalise but to determine the position of student support in one module, which implies academic risk for accounting students.

- Data could have been generated to determine how support students approached their learning differently when they were included in the support group. However, this study was not about learning styles but about student perceptions of support and the potential significance of support.

- A typical limitation to the implementation of support groups is that lecturers may coach students for examinations. Every effort was made, in this particular case, to ensure that this did not happen during its implementation up to the present.

Since the study was conducted, students were admitted to Financial Accounting 178 purely on the basis of the new high school curriculum which was implemented in 2005. It may be beneficial, in follow-up studies, to investigate whether new intakes of students may need academic support and also whether and how their academic performance may differ from previous years. Also, further research may need to determine how successful support group students perform in their second and third years of study. Since 2012, students have also participated in another support programme in the Bachelor of Accounting degree at Stellenbosch University; namely, the Individual Learning and Assistance Programme (ILP). In this programme, students who achieved poorly in their first year are identified and they are required to attend one additional tutorial class per week per major subject together with Thuthuka students.

Universities run academic support initiatives worldwide in order to improve retention rates (Joubert, 2010). Support programmes, such as tutorials and peer mentoring, have been found to influence first-year mathematics and accounting students positively (Maree, Louw \& Millard, 2004; Fox \& Stevenson, 2006). From a South African perspective, Huysamen (2000) has previously stated that the introduction of university academic support and bridging courses to cater to previously disadvantaged students may significantly improve the success of such students. This was largely confirmed by the study reported in this article.

\section{AUTHOR INFORMATION}

Eloise de Jager is a Financial Accounting lecturer at Stellenbosch University. Eloise has recently received the rector's award for excellence in teaching at Stellenbosch University and was selected by the students as the best pregraduate lecturer in the Faculty Economic and Business Sciences. E-mail: edejager@sun.ac.za (Corresponding author)

Dr. Eli Bitzer is a past president of the South African Association for Research and Development in Higher Education, a consulting editor of local and international scientific journals and co-ordinator of several higher education development projects. He supervises masters and doctoral students in higher education higher education studies, Stellenbosch University and has recently edited two books: 'Higher Education in South Africa: A scholarly look behind the scenes' and 'Curriculum Inquiry in South African Higher Education: Some scholarly affirmations and challenges'. As an established researcher Dr Bitzer has recently received the rector's award for excellence in higher education research at Stellenbosch University.

\section{REFERENCES}

1. Accountancy SA. (2008). Special report Thuthuka. Retrieved from: http://www.accountancysa.org.za/ASAJuly08pgs24-37.pdf

2. Adonis, C. (2001). An evaluation of students' perceptions of a multi-faceted support program in a large, diverse first year class. Paper presented at the First Year in Education Conference, Queensland University of Technology, Brisbane. 
3. Albrecht, W. S. \& Sack, R. J. (2000). Accounting education: Charting the course through a perilous future. Accounting Education Series, 16. Sarasota, FL: Author.

4. Ballantine, J. \& McCourt Larres, P. (2009).Accounting undergraduates' perceptions of cooperative learning as a model for enhancing their interpersonal and communication skills to interface successfully with professional accountancy education and training. Accounting Education: an international journal, 18(4-5): 387-402.

5. Bennett, J., Green, G., Rollnick, M. \& White, M. (2001).The development and use of an instrument to assess students' attitudes to the study of science. Journal of SAARMSTE, 5:1-12.

6. Biggers, M., Yilmaz, T., \& Sweat, M. (2009).Using Collaborative, Modified Peer Led Team Learning To Improve Student Success and Retention in Intro CS. ACM SIGCSE Bulletin, March 2009.

7. Biggs, J. (1999). Teaching for quality learning at university. What the student does. Maidenhead: Society for Research into Higher Education \& Open University Press.

8. $\quad$ Braxton, J. (Ed.). (2000). Reworking the student departure puzzle. Nashville: Vanderbilt University Press.

9. Bush, Jr. J.L. (1985). A peer tutoring program for introductory accounting courses. Journal of Accounting Education, 3(2):171-177.

10. Byrne, M. \& Flood, B. (2005).A study of accounting students' motives, expectations and preparedness for higher education. Journal for Further and Higher Education, 29:111-124.

11. Caldwell, M.B., Weishar, J. \& Glezen, G.W. (1996).The effect of cooperative learning on student perceptions of accounting in the principles courses. Journal of Accounting Education, 14(1):17-36.

12. Carpenter, V., Friar, S. \& Lipe, M. (1993). Evidence on the performance of accounting students: race, gender, and expectations. Issues in Accounting Education, 8(1):1-17.

13. Cottell, Jr. P.G. \& Millis, B.J. (1992).Cooperative learning in accounting. Journal of Accounting Education, 10:95-111.

14. Crabtree, H., Roberts, C. \& Tyler, C. (2007).Understanding the problems of transition into higher education. Retrieved from: http://www.ece.salford.ac.uk/proceedings/papers/35_07.pdf

15. Creswell, J.W. (1994). Research design: Qualitative and quantitative approaches. Thousand Oaks. CA: Sage Publications.

16. Crosling, G.M. \& Webb, G. (2002).Supporting student learning: Case studies, experience \& practice from higher education. London: Kogan Page.

17. Cross, M. (2004). Institutionalising campus diversity in South Africa higher education: Review of diversity scholarship and diversity education. Higher Education, 48:339-359. Netherlands: Kluwer Academic Publishers.

18. De Klerk, E., Schoeman, A., Van Deventer, I. \& Van Schalkwyk, S. (2006). The extended degree programmes at Stellenbosch University (1995-2004): An impact study. Unpublished document.

19. Dillenbourg, P. (1999). What do you mean by collaborative learning?. In P. Dillenbourg (Ed) Collaborative-learning: Cognitive and Computational Approaches, 1-19. Oxford: Elsevier.

20. Du Plessis, A., Prinsloo, P. \& Muller, H. (2005).Determining the profile of successful first year Accounting student. The South African Journal of Higher Education, 19(4):684-698.

21. Entwistle, N.J. (1998). Approaches to learning and forms of understanding, in: B. Dart and G.B. Lewis, eds, Teaching and Learning in Higher education (Australian Council for Educational Research, Melbourne, Vic.), 72-101.

22. Evenson, D.H. (2004). To group or not to group: Students' perceptions of collaborative learning activities in law school. Southern Illinois University Law Journal, 28:343-421.

23. Fourie, A.M. (2006). The gap in accounting between secondary and tertiary education at Tshwane University of Technology. Magister Technologiae: Business Administration. Unpublished thesis.

24. Fox, A. \& Stevenson, L. (2006).Exploring the effectiveness of peer mentoring of accounting and finance students in higher education. Accounting Education: An International Journal, 15(2):189-202.

25. Greenwood, C. R., Delquadri, J., \& Hall, R. V. (1989). Longitudinal effects of classwide peer tutoring. Journal of Educational Psychology, 81:371-383.

26. Gross, A.E. \& McMullen, P.A. (1983). Models of help-seeking process. In F.D. Fisher, A. Naples \& B.M. de Paul, New Directions in Helping and Help-seeking, Volume 2. New York: Academic Press.

27. Hall, M.C., Hendriksen, S.I., Love, B. \& Yang, L. (2005).Assessing academic support: the effects of tutoring on student learning outcomes. Journal of College Reading and Learning, 35(2):56-65. 
28. Horn, P., Jansen, A. \& Yu, D. (2008).What explains the academic success of second-year economics students? An exploratory analysis. Stellenbosch economic working papers: 22/08. University of Stellenbosch.

29. Hughes, G. (2007). Using blended learning to increase learner support and improve retention. Teaching in Higher Education, 12(3):349-363.

30. Huysamen, G.K. (2000). The differential validity of matriculation and university performance as predictors of post-first-year performance. South African Journal of Higher Education, 14(1):146-151.

31. Isaacs, D. (2007). Tutoriaalprogram vir openbare en ontwikkelingsbestuur - Bystand aan eerstejaars. [Tutorial programme for public and development management - Support for first-years] Retrieved from: http://academic.sun.ac.za/sol/tmsu/KOL/2007feb/hoofart

32. Johnston, V. (1997). Why do first year students fail to progress to their second year? An academic staff perspective, paper presented at the British Educational Research Association Annual Conference, York, September. Retrieved from: http://www.leeds.ac.uk/educol/documents/000000453.htm

33. Jones, D. J., \& Watson, B. C. (1990). "High-risk" students and higher education: Future trends. ASHEERIC Higher Education Report No. 3. Washington, DC: The George Washington University, School of Education and Human Development. Retrieved from: http://web.ebscohost.com.ez.sun.ac.za/ehost/\%09\%09\%09\%09 - bib40up

34. Joubert, J.A. (2010). Significant predictors of success and non-completion in first year accounting at a South African University. University of the Free State: Unpublished PhD dissertation.

35. Lee, C. (2005). Strategies for promoting active learning in tutorials: Insights gained from a first-year accounting subject. Accounting and Finance Association of Australia and New Zealand Annual Conference 2005, Melbourne, 3-5 July.

36. Leveson, L. (1999). Small group work in accounting education: An evaluation of a programme for firstyear students. Higher Education Research \& Development, 18:361-77.

37. Lizzio, A., Wilson, K. \& Simons, R. (2002). University Students' perceptions of the learning environment and academic outcomes: implications for theory and practice. Studies in Higher Education, 27(1):27-63.

38. Lomofsky, L. \& Lazarus, S. (2001). South Africa: first steps in the development of an inclusive education system. Cambridge Journal of Education, 31(3):303-317.

39. Lord, B.R. \& Robertson, J. (2006). Students' experiences of learning in a third-year management accounting class: Evidence from New Zealand. Accounting Education: an international journal, 15(1):4159.

40. Mabokela, R.O. \& Mawila, K.F.N. (2004).The impact of race, gender and culture in South African Higher Education. Comparative Education Review, 48(4):396-416.

41. Maree, J.G., Louw, C.J. \& Millard, S. (2004). Die impak van tutoriale op die wiskundeprestasie van eerstejaarstudente [The impact of tutorial on mathematics performance of first-year students]. SA Tydskrif vir Natuurwetenskap en Tegnologie, 23(1\&2):25-34.

42. Martins, P. \& Walker, I. (2005).Student achievement and education production: A case-study of the effect of class attendance. Discussion paper. University of Warwick.

43. McDowell, C., Werner, L., Bullock, H.E. \& Fernald, J. (2006). Pair programming improves student retention, confidence, and program quality. Communications of the ACM, 49(8):90-95.

44. McInnis, C. \& James, R. (1995).First year on campus: Diversity in the initial experiences of Australian undergraduates. Canberra: Australian Government Publishing Service.

45. Muller, H., Prinsloo, P. \& Du Plessis, A. (2007).Validating the profile of a successful first year accounting student. Meditari Accounting Research, 15(1):19-33.

46. Murray-Harvey, R. \&Slee, P. (2000).Problem based learning in teacher education: Just the beginning! Paper presented at the annual conference of Australia Association for Research in Education, Sydney, Australia. 4-6 December 2000.

47. Neves, O (Ed).( 2008). South Africa's high university drop-out rates: Why and what can be done? Eduloan News. Retrieved from: http://www.eduloan.co.za/news

48. Prinsloo, P. \& Van Rooyen, A.A. (2007).Exploring a blended learning approach to improving student success in the teaching of second year accounting. Meditari Accounting Research, 15(1):51-69.

49. Richardson, R.C., Jr., \& Bender, L.W. (1987). Fostering minority access and achievement in higher education. San Francisco: Jossey-Bass. 
50. Sadler, E. \& Erasmus, B.J. (2005). The academic success and failure of black chartered accounting graduates in South Africa: A distance education perspective. Meditari Accountancy Research, 13(1): 29-50.

51. Scott I. (2009). Academic development in South African higher education. In Bitzer E (ed): Higher education in South Africa. A scholarly look behind the scenes. Stellenbosch: Africa Sun Media.

52. Scott, I., Yeld, N. \& Hendry, J. (2007). A case for improving teaching and learning in South African higher education. University of Cape Town: Research report for the Council on Higher Education. October.

53. Sideridis, G.D. \& Kaissidis-Rodafinos, A. (2001).Goal importance within planned behaviour theory as 'the' predictor of study behaviour in college. British Journal of Educational Psychology, 71(4):595-618.

54. Siegel, B. (2007). Creating 'institutions of meaning' one by one. Kampusnuus. 31 May 2007. Stellenbosch.

55. Steenkamp, L.P., Baard, R.S. \& Frick, B.L. (2009). Factors influencing success in first-year accounting at a South African university: A comparison between lecturers' assumptions and students' perceptions. SA Journal of Accounting Research, 23(1):113-140.

56. Steinert, Y. (2004). Student perceptions of effective small group teaching. Medical Education, 38(3):286293.

57. Tait, A. (2000). Planning student support for open and distance learning. Open Learning, 15(3):287-299.

58. Tinto, V. (1975). Dropout from higher education: A theoretical synthesis of recent research. Review of Educational Research, 45:89-125.

59. Tinto, V. (2002). Promoting student retention: Lessons learned from the United States. Paper presented at the 11th Annual Conference of the European Access Network, Prato, Italy.

60. Watson, J. (2000). A Peer Assistance Support Scheme (PASS) for first year core subjects. Paper presented at the 4th Pacific Rim First-Year in Higher Education Conference, Brisbane, 5-7 July.

61. Williams, J.R., Tiller, M.G., Herring III, H.C. \& Schiener, J.H. (1988).A framework for the development of accounting education research. Sarasota, FL: American Accounting Association.

62. Wood, L.A. \& Olivier, M.A.J. (2004). A self-efficacy approach to holistic student development. South African Journal of Higher Education, 24(4):289-294. 
NOTES 